\title{
Performance of 'Seyval Blanc' Grape in Four Training Systems Over Five Years
}

\author{
D. Ferree, T. Steiner, J. Gallander, D. Scurlock, G. Johns, and \\ R. Riesen \\ Department of Horticulture and Crop Science, Ohio State University, \\ Wooster, OH 44691 \\ Additional index words. grapevine, wine, French-hybrid
}

\begin{abstract}
Own-rooted 'Seyval Blanc' vines were evaluated over 5 years in the following training systems: bilateral cordon, bilateral cordon sylvos (sylvos), upright cordon-spur pruned, and upright cordon-cane pruned. Vines in all systems were spaced $1.8 \times 2.7 \mathrm{~m}$ and were shoot thinned to 40 shoots and cluster thinned to one cluster per shoot. Cumulative yields over 5 years of the upright cordon systems were higher than vines in the sylvos system. Average weight of cane prunings was higher in the upright cordon vines than in all other systems. Vines trained to the sylvos system had more canopy gaps, less Botrytis bunch rot, and higher juice soluble solids than other systems in some years. The chemical constituents of the must and wine or evaluation by tasting showed little influence of training system.
\end{abstract}

Grapevine orientation in space through the training system has significant effects, particularly on light distribution through the canopy. These alterations in microclimate affect growth, yield, disease development, and fruit composition. The French-American hybrid cultivar Seyval Blanc causes particular challenges because of its tendency to overcrop resulting from production of fruiting shoots from noncount buds, and large relatively compact clusters subject to bunch rot. A number of studies have evaluated training systems for 'Seyval Blanc' with most emphasizing the need for cluster thinning and comparison of various pruning severities (Morris et al., 1984; Reynolds et al., 1985, 1986; Reynolds and Wardle, 1994; Smithyman et al., 1997). Reynolds et al.(1986) recommended levels of 4 shoots $/ 30 \mathrm{~cm}$ of row and 17 clusters $/ 500 \mathrm{~g}$ cane prunings to maximize yield and maintain reasonable fruit quality and vine size.

Divided canopy training systems have been shown to improve yields and fruit quality, particularly under conditions of excess vigor (Henry, 1992; Morris et al., 1984; Reynolds et al., 1996; Reynolds and Wardle, 1994; Shaulis et al., 1966). In several European countries, vertical cordon training has been used to divide canopies using existing trellis configurations. Kiefer et al. (1985) found vertical cordon-trained 'Riesling' vines out-yielded other systems. The upright cordon system has not been evaluated on 'Seyval Blanc' and may be advantageous if a conventional trellis system could be utilized to create a divided canopy.

Since pruning severity and crop level have been shown to have large influences on 'Seyval Blanc' performance, these were held constant in our study. The objective of this study was to determine the influence of four training sys-

Received for publication 28 Sept. 2001. Accepted for publication $27 \mathrm{Feb}$. 2002. Salaries and research support provided by State and Federal funds appropriated to the Ohio Agricultural Research \& Development Ctr., Ohio State Univ. Manuscript \#HCS 01-11.
In 1990, own-rooted 'Seyval Blanc' were planted at a spacing of $1.8 \times 2.7 \mathrm{~m}$ in east-west rows on a Bogart loam soil at the Kingsville

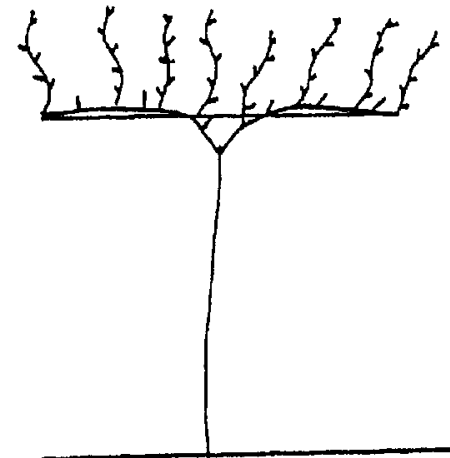

Bilateral Cordon

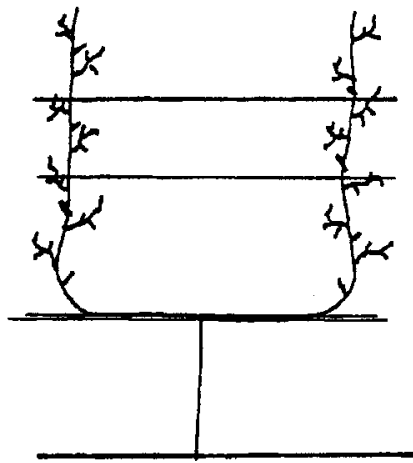

Upright Cordon - Spur Blanc' vines beginning in 1990 .
Grape Branch of Ohio State Univ. located adjacent to Lake Erie. Soil management was a 1.0-m herbicide strip with mowed sod middles. During the first 2 years, vines were trained to a stake to achieve straight trunks and in the third year trained to the following systems: 1 ) bilateral cordon; 2) bilateral cordon sylvos (sylvos); 3) upright cordon-spur pruned; and 4) upright cordon-cane pruned (Fig. 1). All systems were dormant pruned annually to leave a total of 40 count buds. Around bloom, shoot number was adjusted to 40 and each shoot was cluster thinned to one cluster per shoot. In the bilateral cordon, the two cordons were fastened to the top wire $(1.6 \mathrm{~m})$. At pruning, three 5 -bud canes plus spurs totaling 20 buds were left on each side, and after cluster thinning the shoots were positioned. In the sylvos, seven to nine-bud canes were arched over a wire at 1.2 $\mathrm{m}$ and tied to a lower wire $(0.8 \mathrm{~m})$. Catch wires were used to vertically train the developing shoots. In July, shoots were tipped $30-40 \mathrm{~cm}$ above the top wire $(1.6 \mathrm{~m})$. Upright cordons were trained with two equal cordons in the shape of a "U" with shoots developing in the bottom of the " $U$ " $(0.8 \mathrm{~m})$ removed, thus, creating an open space or diversion of the canopy. In the spur-pruned version, 20 buds were left on each side in two-to-three bud spurs and in the cane pruned version, three 5bud canes were left on each side plus spurs to equal 40 buds. The upright cordon systems received no shoot positioning or summer tip-

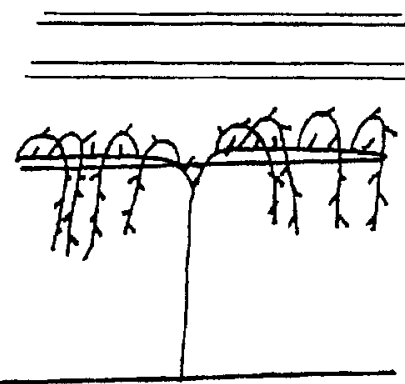

Sylvos

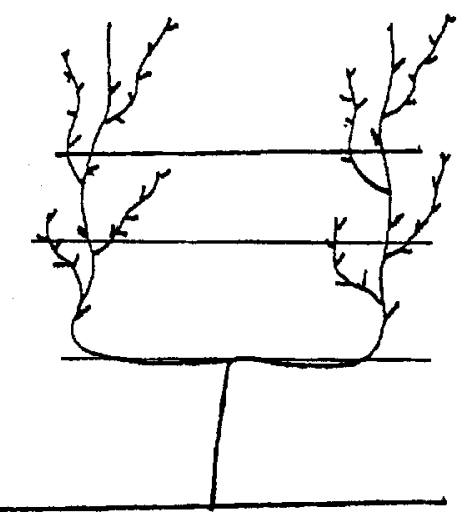

Upright Cordon - Cane

Fig. 1. Diagrams of orientation after dormant pruning of four training systems used for own-rooted 'Seyval 
ping. Whole rows of nine vines of each training system were arranged as a randomized block with four replications for a total of 36 vines for each training system.

The following data were annually recorded: cluster number and weight per vine, pruning time, and weight of cane prunings. At harvest, a 100-berry sample was taken from each row, weighed and pressed through a fruit strainer to collect the juice. Soluble solids were measured using a refractometer (model $10480 \mathrm{~S} / \mathrm{N}$; Abbe AO Scientific Instruments, Keene, N.H.). Measurements of $\mathrm{pH}$ were taken using a calibrated digital ionalyzer (model 701A; Orion Research, Cambridge, Mass.). TA was determined by diluting $5 \mathrm{~mL}$ of juice into $100 \mathrm{~mL}$ of double-distilled water and titrating with a standardized $\mathrm{NaOH}$ solution until the solution reached a $\mathrm{pH}$ of 8.2.

Canopy light interception was measured in 1996-98 early in the season just as growth started, mid-season and just prior to harvest on three vines in each replication. A white plastic sheet $1.8 \times 2.7 \mathrm{~m}$ and marked on $15-\mathrm{cm}$ squares was placed on the soil surface with the vine placed in the center. The sheet covered the soil area allotted to each vine. On sunny days, the number of marks in shadow were counted at about 10:00 AM and 2:00 PM and used to calculate the percentage of light interception. A comparison of this method and the use of actual light sensors showed a very high correlation (Wunsche et al., 1995).

Canopy density was measured annually except for 1995 using the point quadrant method using intersections every $15 \mathrm{~cm}$ at $1.0 \mathrm{~m}$ and $1.5 \mathrm{~m}$ above the soil surface (Smart and Robinson, 1990). Measurements were made on five vines in each replication avoiding the end vines. Fruit distribution in the canopy was measured by placing a frame with a grid marked in $25-\mathrm{cm}$ squares and counting the clusters in each square just prior to harvest. The frame was centered on the trunk and three vines per replication were measured.

Immediately after harvest, the grapes were transported to the winemaking facilities at OARDC and cooled overnight at $35^{\circ} \mathrm{F}$. The following day they were destemmed and crushed and treated with potassium metabisulfite $\left(50 \mathrm{mg} \cdot \mathrm{L}^{-1}\right)$. Biopectinase $300 \mathrm{~L}$ $\left(0.4 \mathrm{~mL} \cdot \mathrm{L}^{-1}\right.$ of $10 \%$ solution of Biopectinase in water) was added and the must settled overnight at $35^{\circ} \mathrm{F}$. The clear must was racked off, chaptalized to $20^{\circ} \mathrm{Brix}$, supplemented with diammonium phosphate (DAP) at $1 \mathrm{~g} \cdot \mathrm{L}^{-1}$ and inoculated with rehydrated dry wine yeast at $0.25 \mathrm{~g} \cdot \mathrm{L}^{-1}$. Each treatment was fermented to dryness at $60^{\circ} \mathrm{F}$ in triplicates in 20 - $\mathrm{L}$ glass containers. At dryness, the wines were racked into $12-\mathrm{L}$ glass containers, treated with potassium metabisulfite $\left(50 \mathrm{mg} \cdot \mathrm{L}^{-1}\right)$ and held at $35^{\circ} \mathrm{F}$ for 3 months. The free $\mathrm{SO}_{2}$ content was adjusted to $30 \mathrm{mg} \cdot \mathrm{L}^{-1}$ and the wines bottled.

Fifteen experienced judges were asked to rate the wines for aroma, taste, and overall quality on a numerical scale from 1-9, where $1=$ excellent and $9=$ extremely poor. The wines $(50-\mathrm{mL}$ samples) were evaluated at room temperature in three flights of four wines in glasses coded with randomized 3digit numbers. Each flight consisted of one replicate of each training system.

\section{Results}

Even with annual cluster thinning, yields of 'Seyval Blanc' were slightly influenced by training system in three out of five years (Fig. 2). There was a tendency for the upright cordon-cane pruned vines to have higher yields and sylvos trained vines to have lower yields, but differences were not always significantly different. Cumulative yield of the upright cordon systems, both spur and cane pruned, were significantly higher than vines trained to the sylvos system (Table 1). Average pruning weight from upright cordon spur pruned vines was higher than for all the other systems, which were similar to each other. The pruning time required per vine was highest for the bilateral cordon system and lowest for the sylvos and upright cordon-spur pruned vines. Although bunch rot levels were low most years and not influenced by training systems, in 1997 bunch rot was present and vines trained in the sylvos system had lower rot levels than both of the upright cordon systems. A comparison of the average chemical components of the juice show no influ- ence of training system on soluble solids concentration or titratable acidity (Table 1). However, $\mathrm{pH}$ of fruit from upright cordonspur pruned vines was lower than bilateral cordon fruit.

A grid placed by the vine at harvest showed that the bilateral cordon concentrated the crop in the upper levels of the canopy and distributed it evenly from the trunk to the canopy edge. The upright cordon systems had an even distribution of the crop over the fruiting canopy, while the crop on the sylvos vines were distributed lower in the canopy and had less of the crop at the canopy edge than the other systems (data not presented).

An analysis of the canopy using the point quadrant system shows a tendency for fewer gaps, more leaf layers and greater percentage of interior leaves for vines trained as an upright cordon-spur pruned vine (Fig. 3). In 1997 , the year sylvos vines had a lower amount of bunch rot, the canopy of sylvos trained vines tended to have more gaps and fewer interior leaves.

Vine light interception increased as expected as the canopy developed and reached a maximum around harvest, intercepting $40 \%$ to $50 \%$ of available light (Table 2). Measurements early in the season indicate that the bilateral cordon trained vines tended to intercept more light than the sylvos, but differences

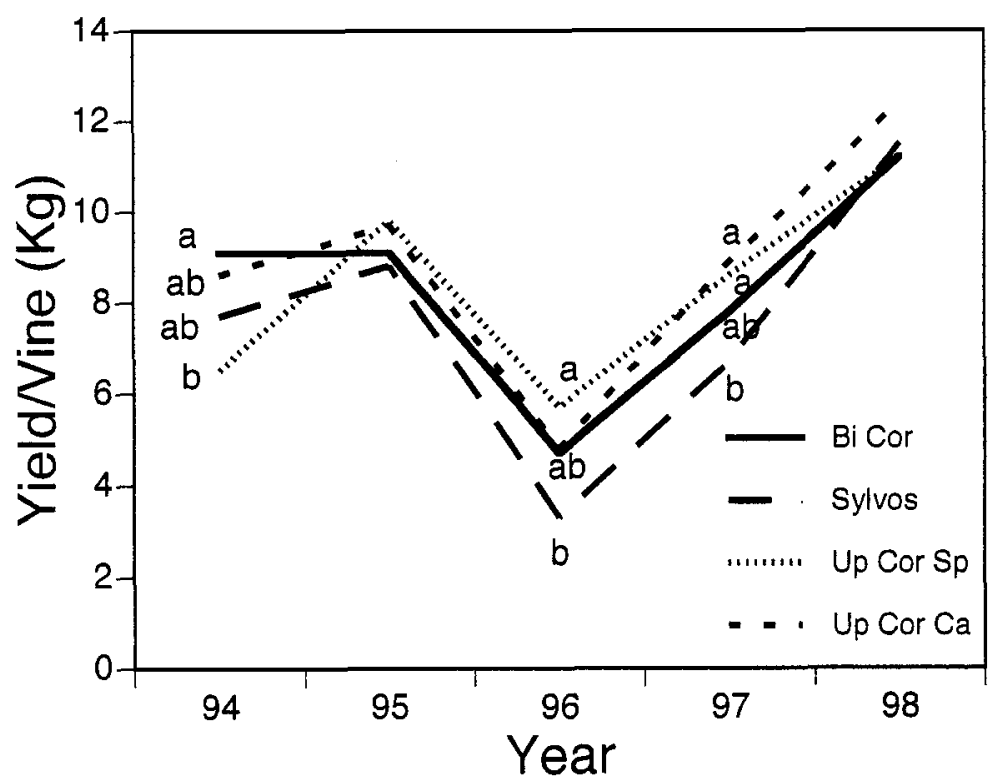

Fig. 2. Yield per vine of 'Seyval Blanc' in the following four training systems: Bilateral cordon (BiCor), Sylvos, Upright cordon-spur (Up Cor Sp), Upright cordon-cane (Up Cor Ca). Mean separation by Duncan's multiple range test $P \leq 0.05$.

Table 1.Influence of four training systems on cumulative yield and average cane pruning weight, pruning time, and juice quality components over 1994 through 1998.

\begin{tabular}{|c|c|c|c|c|c|c|c|}
\hline \multirow[b]{2}{*}{ Training system } & \multirow{2}{*}{$\begin{array}{c}\text { Avg } \\
\text { yield/vine } \\
(\mathrm{kg})\end{array}$} & \multirow{2}{*}{$\begin{array}{c}\text { Avg } \\
\text { cane pruning } \\
\text { wt/vine }(\mathrm{kg})\end{array}$} & \multirow{2}{*}{$\begin{array}{c}\text { Pruning } \\
\text { time } \\
\text { min/vine }\end{array}$} & \multirow{2}{*}{$\begin{array}{r}1997 \\
\text { \% rot }\end{array}$} & \multicolumn{3}{|c|}{ Avg juice components } \\
\hline & & & & & $\overline{\mathrm{SSC}}$ & $\mathrm{pH}$ & TA $g \cdot L^{-1}$ \\
\hline Bilateral Cordon & $8.3 \mathrm{ab}^{\mathrm{z}}$ & $0.58 \mathrm{~b}$ & $2.11 \mathrm{a}$ & $9.3 \mathrm{ab}$ & 18.9 & $3.16 \mathrm{a}$ & 10.2 \\
\hline Sylvos & $7.6 \mathrm{~b}$ & $0.54 \mathrm{~b}$ & $1.78 \mathrm{~b}$ & $3.0 \mathrm{~b}$ & 19.0 & $3.15 \mathrm{ab}$ & 10.2 \\
\hline Upright cordon-spur & $8.5 \mathrm{a}$ & $0.93 a$ & $1.90 \mathrm{ab}$ & $12.5 \mathrm{a}$ & 19.1 & $3.13 \mathrm{~b}$ & 10.3 \\
\hline Upright cordon-cane & $8.7 \mathrm{a}$ & $0.72 \mathrm{~b}$ & $1.85 \mathrm{ab}$ & $10.3 \mathrm{a}$ & 19.1 & $3.14 \mathrm{ab}$ & 10.2 \\
\hline
\end{tabular}

${ }^{2}$ Mean separation by Duncan's multiple range test, $P \leq 0.05$ 
were not always significantly different from the other systems. At harvest, sylvos trained vines tended to intercept less light and the upright cordon vines the most light with interception in the other systems being similar or different from the extremes depending on the year.
The must analysis is probably the best reflection of the effect of training system on juice chemical components because it encompasses a large sample. Soluble solids concentration in the must from the sylvos system were higher than found in the upright cordonspur pruned vines in 1996 and 1997 with the
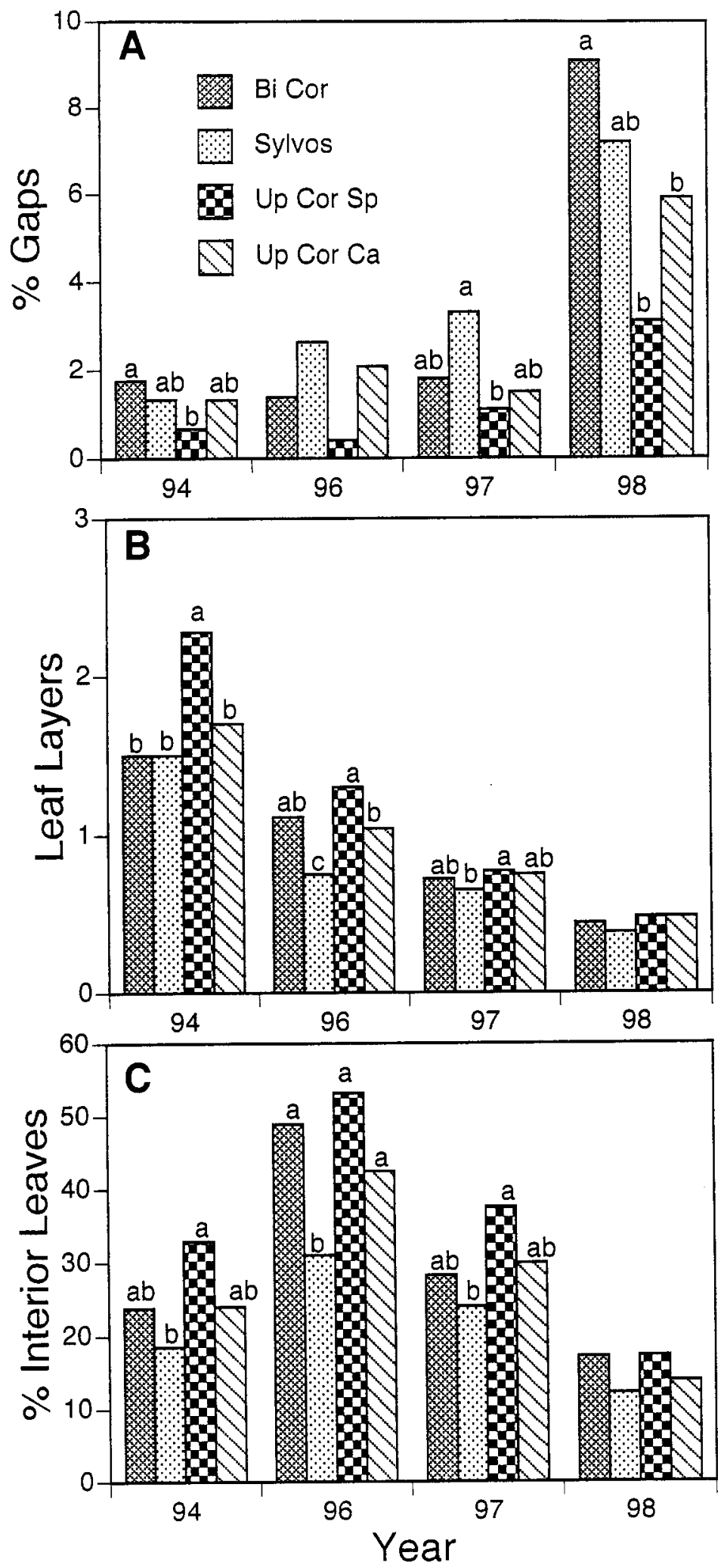

Fig. 3. Canopy composition significant interaction, between year and training systems on 'Seyval Blanc' grapevines as measured by the point quadrant system: $(\mathbf{A})$ percentage of gaps, $(\mathbf{B})$ leaf layers, (C) percentage of interior leaves. Mean separation by Duncan's multiple test, $P \leq 0.05$. reverse occurring in 1995 (Table 3). Must $\mathrm{pH}$ was high from the bilateral cordon in 1996 and 1998 , but did not differ from one or more of the other training systems. Although there were differences in titratable acidity in two of the five years, consistent influence of system was not apparent. Although these training systems displayed the canopy in very different ways, the effect on must composition was small and not consistent over the years.

Chemical analysis of the finished wine found no significant difference in volatile acidity in any year (data not presented). Wine $\mathrm{pH}$ was affected only in 1996 with wine produced from the upright cordon-cane pruned vines being higher than from the sylvos system.

A panel of 15 winemakers evaluated the wine from 1997 and 1998 and found that in 1997, wine from the upright cordon-spur pruned vines had better aroma than the wine from the sylvos and upright cordon-cane pruned vines (Table 5). Overall quality of the upright cordon-spur pruned vines was also judged superior to the upright cordon-cane pruned vines. The judges found no effect of training system on wine aroma, taste or quality in 1998.

\section{Discussion}

Since crop was limited to one cluster per shoot and vines in all systems had 40 shoots, it was anticipated that yield would be similar among systems. There was no difference in cluster weight or berry size in any year among the systems. The slightly lower (10\%) cumulative yields in the sylvos system was likely related to the lower cluster number per vine in 1996 and 1997. Bending the canes down has been shown to reduce vegetative growth of grapes (Reynolds et al., 1985; Schubert et al., 1999) and likely resulted in the reduced pruning weight, smaller vine size and lower yield of vines in the sylvos system. Since some canes and many shoots were also oriented downward (but not tied in this position) in the bilateral cordon, this may explain the lower pruning weight in this system compared to the upright cordon system. Training the cordons upright and pruning to two or three bud spurs increased vegetative vigor and resulted in a higher pruning weight compared to other systems.

Another concept that is widely used as a measure of the balance between vegetative growth and cropping is crop load (yield $\div$ pruning weight). A calculation from the recommended optimum for 'Seyval Blanc' by Reynolds et al. (1986A) gives a value of $10-\mathrm{kg}$ fruit per kilogram of pruning weight. In the present study, the averaged calculated crop loads were as follows: bilateral cordon 14.3, sylvos 14.0, upright cordon spur 9.1, and upright cordon cane 12.0. Values recommended for $V$, vinifera cultivars are generally below 10 to maintain an optimum balance between growth, yield, and wine quality (Bravdo et al., 1984). Ferree et al. (2002) reported an average crop load of 14 for 'Vidal Blanc' another French-American hybrid with vines apparently in balance. This data may suggest that the optimum crop load for French- 
Table 2. Influence of four training systems on percentage of light interception of 'Seyval Blane' vines over the season using the dot/shade method.

\begin{tabular}{|c|c|c|c|c|c|c|}
\hline \multirow[b]{3}{*}{ Training system } & \multicolumn{6}{|c|}{ Light interception $(\%)$ time of season } \\
\hline & \multicolumn{2}{|c|}{ Early } & \multicolumn{2}{|c|}{ Mid } & \multicolumn{2}{|c|}{ Late } \\
\hline & AM & $\mathrm{PM}$ & $\mathrm{AM}$ & $\overline{\mathrm{PM}}$ & $\mathrm{AM}$ & $\mathrm{PM}$ \\
\hline \multicolumn{7}{|c|}{1996} \\
\hline Bilateral Cordon & $16 \mathrm{a}^{z}$ & $13 \mathrm{a}$ & 22 & $27 \mathrm{a}$ & $52 \mathrm{a}$ & $51 \mathrm{ab}$ \\
\hline Sylvos & $11 b$ & $10 \mathrm{~b}$ & 17 & $16 \mathrm{c}$ & $42 \mathrm{~b}$ & $43 \mathrm{~b}$ \\
\hline Upright cordon-spur & $12 a b$ & $11 \mathrm{ab}$ & 22 & $22 \mathrm{~b}$ & $52 \mathrm{a}$ & $55 \mathrm{a}$ \\
\hline Upright cordon-cane & $12 a b$ & $10 \mathrm{~b}$ & 19 & $20 \mathrm{~b}$ & $51 \mathrm{a}$ & 53 a \\
\hline \multicolumn{7}{|c|}{1997} \\
\hline Bilateral cordon & $17 \mathrm{a}$ & $9 \mathrm{a}$ & $35 \mathrm{a}$ & 32 & $44 \mathrm{~b}$ & $35 \mathrm{ab}$ \\
\hline Sylvos & $13 \mathrm{~b}$ & $14 b$ & $27 b$ & 26 & $42 b$ & $33 \mathrm{~b}$ \\
\hline Upright cordon-spur & $14 \mathrm{ab}$ & $17 \mathrm{ab}$ & $34 \mathrm{a}$ & 32 & $51 \mathrm{a}$ & $42 \mathrm{a}$ \\
\hline Upright cordon-cane & $13 \mathrm{~b}$ & $15 \mathrm{~b}$ & $32 \mathrm{a}$ & 29 & $50 \mathrm{a}$ & $42 \mathrm{a}$ \\
\hline \multicolumn{7}{|c|}{1998} \\
\hline Bilateral cordon & 6 & 6 & $30 \mathrm{a}$ & 25 & $49 a b$ & $46 \mathrm{ab}$ \\
\hline Sylvos & 5 & 5 & $24 a b$ & 21 & $46 \mathrm{a}$ & $42 \mathrm{~b}$ \\
\hline Upright cordon-spur & 6 & 5 & $22 \mathrm{~b}$ & 22 & $55 \mathrm{a}$ & $52 \mathrm{a}$ \\
\hline Upright cordon-cane & 6 & 5 & $24 a b$ & 21 & $52 \mathrm{a}$ & $47 \mathrm{ab}$ \\
\hline
\end{tabular}

${ }^{2}$ Mean separation by Duncan's multiple test, $P \leq 0.05$.

American hybrid grapes may be slightly higher than for $V$. vinifera cultivars.

Yield of vines in all systems was particularly low in 1996 (Fig. 2). The low yield in 1996 also occurred in commercial vineyards and has been attributed to rainfall above the long-term average in every month of the year (Brown et al., 2001). Average yield/ha in this planting over 5 years ranged from $17.5 \mathrm{t} \cdot \mathrm{ha}^{-1}$ ( $7.0 \mathrm{t} / \mathrm{acre}$ ) with the sylvos system to $20.5 \mathrm{t}$ / ha $(8.3 \mathrm{t} / \mathrm{acre})$ in the cane pruned upright cordon. Except for 1996 when all systems were below the threshold for productive French-American hybrids of $14.8 \mathrm{t} \cdot \mathrm{ha}^{-1}(6.0 \mathrm{t} /$ acre) all exceeded the threshold in other years. Reynolds et al. (1986A) recommended 4 shoots $/ 30 \mathrm{~cm}$ row and 17 clusters $/ 500 \mathrm{~g}$ cane prunings to maximize yield and maintain reasonable fruit quality and vine size of 'Seyval Blanc'. In this study, the vines exceeded that recommendation by 2 shoots $/ 30$ $\mathrm{cm}$ row and 8 clusters $/ 500 \mathrm{~g}$ cane prunings. Although these vines were cropped heavily, there was no trend of reduced growth or yield over the 5-year test period, and in fact, the largest yield and pruning weight occurred in the last year of the study. This consistent performance was likely related to the annual thinning of clusters that has been suggested as a requirement for the successful management of 'Seyval Blanc' (Reynolds et al., 1986a; Smithyman et al., 1997).

Training the vines in the sylvos system distributed the crop lower in the vine and tended to result in a canopy with more gaps, fewer leaf layers, and fewer internal leaves, although the differences were not always statistically significant (Fig. 3). In 1997 when significant Botrytis bunch rot occurred, this more open canopy resulted in less fruit infection. The smaller and more open canopy of vines in the sylvos system was confirmed by the tendency for lower light interception. Fruit from vines in this system had higher soluble solids than fruit from the most vigorous vines (upright cordon-spur pruned). Exposure of 'Seyval Blanc' clusters to light has been shown to positively influence soluble solids (Hummel and Ferree, 1998; Reynolds et al., 1986b).

Dividing the canopy in the upright cordon systems tended to improve yields compared to the sylvos system even with cluster thinning, which confirms reports of Kiefer et al. (1985) of increased yields with this training system. Other studies with other divided canopy systems, particularly the Geneva Double Curtain, have also improved yields of 'Seyval Blanc', but require extensive trellis modification (Morris et al., 1984; Reynolds and Wardle, 1984). Vines trained to the upright cordon system made more vegetative growth, tended to have a denser canopy, particularly when spur pruned, and intercepted more light. Lakso (1994) has shown that light interception is closely related to yield with apple trees grown in a wide range of training systems. Several authors (Morris et al., 1984; Reynolds et al, 1985) have suggested that sustained yield of 'Seyval Blanc' is closely related to grow th measured by cane pruning weight. The increased vegetative growth of the upright cordon-spur pruned vines was associated with improved wine aroma and overall quality in one year, but there was no influence the following year. Other studies (Reynolds et al., 1985, 1986a) evaluating the influence of training systems on 'Seyval Blanc' wine quality also found only minor influences.

All the training systems in this study performed adequately in comparison to the standard bilateral cordon system. The sylvos system reduced growth and resulted in a more open canopy with less Botrytis bunch rot and higher total soluble solids. The upright cordon system tended to increase vegetative growth and yield and provides a means of dividing the canopy using a conventional trellis.

\section{Literature Cited}

Bravdo, B. Y. Hpener, C. Loinger, S. Cohen, and H. Titabacman. 1984. Effect of crop level on growth, yield and wine quality of a high yielding 'Carignanea' vineyard. Amer. J. Enol. Viticult. 35(4):247-252.

Brown, M.V., D.C. Ferree, D.M. Scurlock, and G Sigel. 2001. Impact of soil drainage on growth, productivity, cane dieback and fruit composition of 'Chambourcin' and 'Pinot Gris' grapevines. HortTechnology 11:272-276.

Ferree, D.C., G.A. Cahoon, D.M. Scurlock, and M.V. Brown. 2002. Effect of time of cluster thinning grapevines. Small Fruit Rev. (In Press.) Henry, S. 1992. Scott Henry trellis system. Oregon Wine Grape Growers Guide $4^{\text {th }}$ ed. 119-123. Hummell, A.K. and D.C. Ferree. 1998. Interaction

Table 3. Influence of four training systems on chemical composition of 'Seyval Blanc' must over 5 years (1994-98).

\begin{tabular}{|c|c|c|c|c|c|c|c|c|c|c|c|c|c|c|c|}
\hline \multirow[b]{2}{*}{ Training system } & \multicolumn{5}{|c|}{ Soluble solids concn $(\%)$} & \multicolumn{5}{|c|}{$\mathrm{pH}$} & \multicolumn{5}{|c|}{ Titratable acidity $\left(\mathrm{g} \cdot \mathrm{L}^{-1}\right)$} \\
\hline & 94 & 95 & 96 & 97 & 98 & 94 & 95 & 96 & 97 & 98 & 94 & 95 & 96 & 97 & 98 \\
\hline Bilateral cordon & 17.5 & $18.7 a^{2}$ & $18.0 \mathrm{ab}$ & $19.8 \mathrm{ab}$ & 19.1 & 3.20 & 3.04 & $3.15 \mathrm{a}$ & 3.11 & $3.32 \mathrm{a}$ & 12.0 & 9.7 & $18.9 \mathrm{a}$ & 10.6 & $8.0 \mathrm{ab}$ \\
\hline Sylvos & 18.0 & $17.0 \mathrm{c}$ & $18.7 \mathrm{a}$ & $20.4 \mathrm{a}$ & 19.6 & 3.22 & 3.03 & $3.13 \mathrm{ab}$ & 3.09 & $3.22 \mathrm{~b}$ & 12.3 & 9.8 & $11.8 \mathrm{~b}$ & 10.3 & $8.1 \mathrm{a}$ \\
\hline Upright cordon-cane & 17.9 & $18.5 \mathrm{~b}$ & $18.4 \mathrm{ab}$ & $19.8 \mathrm{ab}$ & 19.5 & 3.20 & 3.02 & $3.12 \mathrm{ab}$ & 3.10 & $3.19 \mathrm{~b}$ & 12.1 & 9.4 & $12.5 \mathrm{a}$ & 10.4 & $8.0 \mathrm{ab}$ \\
\hline
\end{tabular}

${ }^{2}$ Mean separation by Duncan's multiple range test $P \leq 0.05$.

Table 4. Influence of four training systems on chemical composition of 'Seyval Blanc' wine over 5 years (1994-98).

\begin{tabular}{|c|c|c|c|c|c|c|c|c|c|c|}
\hline \multirow[b]{2}{*}{ Training system } & \multicolumn{5}{|c|}{$\overline{\mathrm{pH}}$} & \multicolumn{5}{|c|}{ Titratable acidity $\left(\mathrm{gL}^{-1}\right)$} \\
\hline & 94 & 95 & 96 & 97 & 98 & 94 & 95 & 96 & 97 & 98 \\
\hline Bilateral cordon & 3.12 & 3.10 & $3.29 \mathrm{ab}^{2}$ & 3.25 & $3.45 \mathrm{a}$ & $8.8 \mathrm{a}$ & $7.6 \mathrm{~b}$ & $11.1 \mathrm{a}$ & $11.1 \mathrm{a}$ & 7.6 \\
\hline Sylvos & 3.08 & 2.97 & $3.2 \mathrm{lb}$ & 3.22 & $3.34 \mathrm{~b}$ & $8.7 \mathrm{a}$ & $8.9 \mathrm{a}$ & $10.3 \mathrm{~b}$ & $10.8 \mathrm{ab}$ & 7.6 \\
\hline Upright cordon-spur & 3.11 & 3.10 & $3.23 \mathrm{ab}$ & 3.25 & $3.41 \mathrm{ab}$ & $8.6 \mathrm{ab}$ & $7.4 \mathrm{~b}$ & $11.2 \mathrm{a}$ & $10.8 \mathrm{ab}$ & 7.8 \\
\hline Upright cordon-cane & 3.07 & 3.04 & $3.30 \mathrm{a}$ & 3.22 & $3.35 \mathrm{~b}$ & $8.4 \mathrm{~b}$ & $7.2 \mathrm{~b}$ & $11.0 \mathrm{a}$ & $10.6 \mathrm{~b}$ & 7.9 \\
\hline
\end{tabular}

${ }^{2}$ Mean separation by Duncan's multiple range test $P \leq 0.05$ 
Table 5. Summary of taste evaluation of 'Seyval Blanc' wine as influenced by four training systems.

\begin{tabular}{|c|c|c|c|c|c|c|}
\hline \multirow[b]{2}{*}{ Training system } & \multicolumn{2}{|c|}{ Aroma $^{2}$} & \multicolumn{2}{|c|}{ Taste } & \multicolumn{2}{|c|}{ Overall quality } \\
\hline & 1997 & 1998 & 1997 & 1998 & 1997 & 1998 \\
\hline Bilateral cordon & $3.6 \mathrm{ab}^{y}$ & 3.7 & 3.9 & 3.5 & $3.80 \mathrm{ab}$ & 3.6 \\
\hline Sylvos & $3.76 \mathrm{a}$ & 4.3 & 4.2 & 3.9 & $4.00 \mathrm{ab}$ & 4.1 \\
\hline Upright cordon-spur & $3.28 \mathrm{~b}$ & 3.3 & 3.7 & 3.1 & $3.48 \mathrm{~b}$ & 3.3 \\
\hline Upright cordon-cane & $3.85 \mathrm{a}$ & 3.7 & 4.1 & 3.8 & $4.05 \mathrm{a}$ & 3.8 \\
\hline
\end{tabular}

${ }^{z}$ Average of 15 independent judges using a scale of $1=$ excellent to $9=$ extremely poor.

${ }^{y}$ Mean separation by Duncan's multiple range test $P \leq 0.05$.

of crop level and fruit cluster exposure on 'Seyval Blanc' fruit composition. J. Amer. Soc. Hort. Sci. 123(5):755-761.

Kiefer, W., H.J. Eisenbarth, and M. Weber. 1985. Initial results when testing the vertical training system. Der Deutsche Weinbau, Wiesbaden 40:1122-1125.

Lakso, A.N. 1994. Apple. In: Handbook of environmental physiology of fruit crops. Vol. 1, p. 3-42. B. Schaffer and P.C. Anderson (eds.). CRC Press, Boca Raton, Fla.

Morris, J.R., C.A. Sims, J.E. Bourgue, and J.L. Okes. 1984. Influence of training system, pruning severity and spur length on yield and quality of six French-American hybrid grape cultivars. Amer. J. Enol.Viticult. 35:23-27.
Reynolds, A.G., R.M. Pool, and L.R. Mattick. 1985. Effect of training system on growth, yield, fruit composition and wine quality of 'Seyval Blanc'. Amer. J. Enol.Viticult. 36:156164.

Reynolds, A.G., R.M. Pool and L.R. Mattick 1986A. Effect of shoot density and crop control on growth, yield, fruit composition and wine quality of 'Seyval Blanc' grapes. J. Amer. Soc. Hort. Sci. 111:55-63.

Reynolds, A.G., R.M. Pool, and L.R. Mattick. 1986B. Influence of cluster exposure on fruit composition and wine quality of 'Seyval Blanc' grapes. Vitis 25:85-95.

Reynolds, A.G. and D.A. Wardle. 1994. Impact of training system and vine spacing on vine per- formance and berry composition of 'Seyval Blanc'. Amer. J. Enol. Viticult. 45(4):444451.

Reynolds, A.G., D.A. Wardle, A.P. Naylor. 1996. Impact of training system, vine spacing, and basal leaf removal on 'Riesling' vine performance, berry composition, canopy microclimate, and vineyard labor requirements. Amer. J. Enol. Viticult. 47(1):63-76.

Schubert, A., C. Lovisolo, and E. Peterlunger. 1999. Shoot orientation affects vessel size. shoot hydraulic conductivity and shoot orientation rate in Vitis vinifera L. Plant, Cell and Environ. 22:197-204.

Shaulis, N., H. Amberg, and D. Crowe. 1966 Response of 'Concord' grapes to light, exposure and Geneva Double Curtain training. Proc. Amer. Soc. Hort. Sci. 89:268-280.

Smart, R. and M. Robinson. 1991. Sunlight into wine. Wine Titles, Underdale, South Australia. Smithyman, R.P., G.S. Howell, and D.P. Miller. 1997. Influence of canopy configuration on vegetative development, yield and fruit composition of 'Seyval Blanc' grapevines. Amer. J. Enol. Viticult. 48:482-491.

Wunsche, J.N., A.N. Lakso, and T.L. Robinson. 1995. Comparison of four methods for estimating total light interception by apple trees of varying forms. HortScience 30:272-276. 